\title{
ACRL Continuing Education Courses, Philadelphia
}

ACRL will be sponsoring eight continuing education courses at the ALA Annual Conference in Philadelphia this July. The courses will range in length from one to two days and will deal with the following areas: 1) management; 2) library skills; 3) technology update; 4) the environment; and 5) professional development.

Advance registration by May 31 will be required since enrollment is limited. A late registration fee of $\$ 15$ will be charged. For further information regarding these courses or the ACRL Continuing Education Program in general, contact Barbara Macikas, Program Assistant, ACRL/ALA, 50 E. Huron St., Chicago, IL 60611; (312) 944-6780.

CE 101-Librarians as Supervisors.

CE 103-Establishing the College Bibliographic Instruction Program: The Director's Role.

CE 104-Strategies and Tactics for Enhancing the Role and Position of the Library Within the College or University.

CE 105-Time Management and Conducting Effective Meetings.

CE 201-An Introduction to Maps in Libraries: Maps as Information Tools.

CE 202-Teaching Methods for the Bibliographic Instruction Librarian.

CE 501-Writing the Journal Article and Getting It Published.

CE 503-Survey Research Methods.

\section{Librarians as Supervisors}

CE 101 seeks to provide participants the opportunity to identify the skills necessary to become effective supervisors in library organizations and to develop an awareness and understanding of current managerial concepts and practices. Specific objectives include: to increase selfawareness of behavior and managerial philosophy; to develop a greater appreciation of the supervisor's role and contribution to improving library performance; to gain an understanding of the skills required for effective supervision; and to examine individual approaches to supervision in response to the needs and demands of particular situations.

Instructor: Maureen Sullivan, Training Program Specialist, Office of Management Studies, Association of Research Libraries.

Date: Friday, July 9, 9:00 a.m.-5:00 p.m.

Fee: ACRL members \$95, non-members \$135.

Establishing the College Bibliographic

Instruction Program: The Director's Role

CE 103 will provide an overall review of managerial considerations essential in establishing the successful bibliographic instruction program. Program components examined will include political aspects, staff needs, budgetary support, and faculty administration support. The course will assist the college library administrator in recognizing the major areas in which the library director will intervene when establishing a bibliographic instruction program.

Instructor: Dennis E. Robison, University Librarian, University of Richmond, Richmond, Virginia.

Date: Thursday, July 8, 9:00 a.m. $-5: 00$ p.m.; Friday, July 9, 9:00 a.m.-12:00 noon.

Fee: ACRL members, \$145, non-members $\$ 185$.

Strategies and TaCTICS FOR ENHANCING

Role and Position OF THE LibraRy Within THE College OR UNIVERSITY

CE 104 explores the internal and external factors which influence the library's role within the college or university and develops specific strategies and tactics academic library administrators can employ to more effectively advance the library's position within the institution.

Instructor: P. Grady Morein, University Librarian, Clifford Library, University of Evansville, Indiana.

Date: Thursday, July 8, 9:00 a.m.-5:00 p.m.; Friday, July 9, 9:00 a.m.-12 noon.

Fee: ACRL members $\$ 145$, non-members $\$ 185$.

\section{Time Management and Conducting EfFective MeEtings}

CE 105 will enable participants to: identify the most frequent time problems for themselves and those they work with; establish goals and priorities in relation to their work; identify techniques for managing their time on a daily basis and develop techniques to help others manage time; identify the most frequent and frustrating problems related to committee meetings; determine when a meeting will be the best approach for communicating and problem solving; and identify techniques for creating more effective meetings and how these meetings can be used successfully in different situations.

Instructor: Sheila Creth, Assistant Director, University Library, The University of Connecticut, Storrs.

Date: Thursday, July 8, 9:00 a.m.-5:00 p.m.

Fee: ACRL members \$95, non-members $\$ 135$.

An InTRoduction to Maps In LibraRies: MAPS AS INFORMATION TOOLS

CE 201 explores for the nonspecialist the in- 
formation potential of maps in the academic library environment, as well as acquisitions, collection development, reference and instruction use, and space and equipment requirements.

Instructors: David A. Cobb, Map \& Geography Librarian, University of Illinois-Urbana; Charles A. Seavey, Government Publications and Maps Librarian, University of New Mexico, Albuquerque.

Date: Friday, July 9, 9:00 a.m.-5:00 p.m.

Fee: ACRL members \$95, non-members $\$ 135$.

Teaching Methods FOR THE BIBLIOGRAPHIC INSTRUCTION LIBRARIAN

CE 202 provides participants with basic review and practice in learning theory and instructional methods particularly effective in the bibliographic instruction situation, with emphasis on planning and execution.

Instructor: Cerise Oberman-Soroka, Robert Scott Small Library, College of Charleston, South Carolina.

Date: Thursday, July 8, 9:00 a.m.-5:00 p.m.; Friday, July 9, 9:00-5:00 p.m.

Fee: ACRL members \$195, non-members \$235.

\section{Writing the Journal Article and Getting It Published}

CE 501 will supply participants with an overview of the publishing process and help them de- vise an effective strategy for publishing their work. Topics will include selection of a publishing medium, preparation of the manuscript, submission of the manuscript, and pre- and postpublication matters.

Instructor: Richard D. Johnson, Director of Libraries, State University College, Oneonta, New York (formerly editor of College \& Research Libraries, and co-editor of New Horizons for Academic Librarians, and currently acting editor of Choice).

Date: Friday, July 9, 9:00 a.m.-5:00 p.m

Fee: ACRL members $\$ 95$, non-members $\$ 135$.

\section{Survey Research Methods}

CE 503 seeks to acquaint participants with the methodology involved in conducting survey research, including: sampling techniques, questionnaire design, data reduction and analysis, points to be included in proposals and written reports, and the critical evaluation of surveys found in library literature.

Instructor: Gary A. Golden, Documents Librarian, University Library, University of Illinois-Urbana.

Date: Thursday, July 8, 9:00 a.m. $-5: 00$ p.m.; Friday, July 9, 9:00 a.m.-5:00 p.m.

Fee: ACRL members \$195, non-members $\$ 235$.

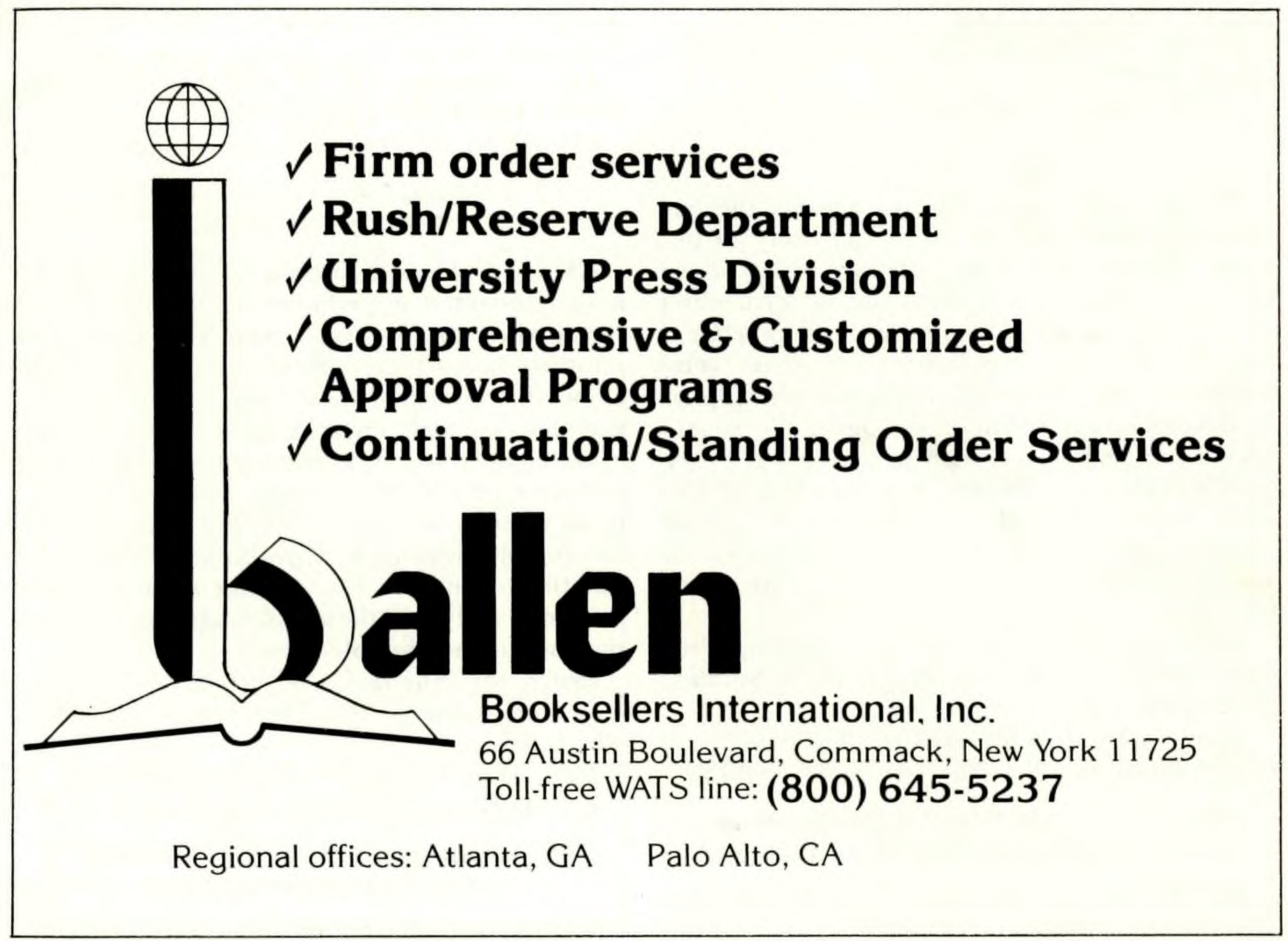




\section{REGISTRATION FORM}

\section{CONTINUING EDUCATION COURSES}

\section{PLEASE PRINT}

NAME

AFFILIATION

STREET

CITY

STATE

ZIP

DAYTIME PHONE

ALA/ACRL MEMBERSHIP \#

PLEASE CIRCLE THE APPROPRIATE DOLLAR AMOUNT FOR THE COURSE OF YOUR CHOICE, AND INDICATE YOUR PREFERENCES IN THE MARGIN (1st, 2nd, and 3rd).

Course

ACRL Member Non-member

CE 101 Librarians as Supervisors

$\$ 95$

$\$ 135$

CE 103 Establishing the College Bibliographic Program: The Director's Role

CE 104 Strategies \& Tactics for Enhancing the Role and Position of the Library Within the College or University

CE 105 Time Management and Conducting Effective Meetings

CE 201 An Introduction to Maps in Libraries: Maps as Information Tools

CE 202 Teaching Methods for the Bibliographic Instruction Librarian

CE 501 Writing the Journal Article \& Getting it Published

\section{ENTER TOTAL AMOUNT ENCLOSED}

\footnotetext{
${ }^{*}$ Fee for registration after May 31.
}

CONFIRMATION: Written confirmations will be made.

CANCELLATIONS: Written notice of cancellations received by June 15 will be honored subject to a $\$ 20$ cancellation charge. No refunds for cancellations received after June 15 .

You may make checks payable to ACRL and return them with this form to:

\section{ACRL-Continuing Education \\ American Library Association \\ 50 E. Huron St. \\ Chicago, IL 60611}

In order to help CE instructors prepare for their courses, please answer the following questions:

1. What do you hope to gain by taking this course?

2. What experience or education have you had in this area prior to enrollment in this CE course? 


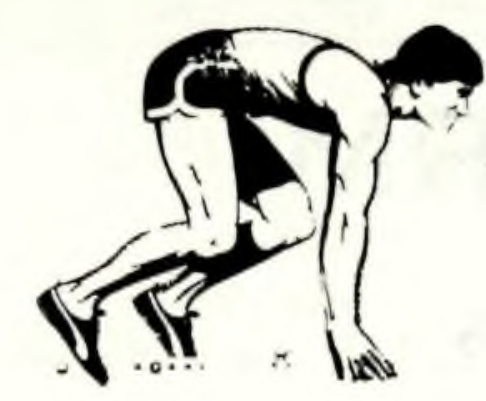

Free: special offer to new subscribers

One volume of the PAIS Bulletin or the PAIS Foreign Language Index valued from $\mathbf{\$ 8 5}$ to $\mathbf{\$ 1 7 5}$

Public Affairs Information Service (PAIS) would like every library to have ready access to information on all the social sciences - from economics to international relations, from public policy to demography. The PAIS Bulletin and its companion service, the PAIS Foreign Language Index, provide such access!

Now, as a special get-aquainted offer, new subscribers to either the 1982 PAIS Bulletin or the 1982 PAIS Foreign Language Index will receive the appropriate bound cumulative volume for 1981 at no charge. In essence, a library will get two years worth of indexing for the price of one - a saving of $\$ 85$ in the case of the Bulletin or \$175 in the case of the Foreign Language Index.

In addition, any subscriber, new or old, wishing to further enhance a PAIS collection may purchase back volumes at $50 \%$ off the regular price. This includes the PAIS Bulletin back to 1969 and all back volumes of the PAIS Foreign Language Index.

These offers are good for any order received by May 15, 1982.

For more information on the 1982 subscription rates and options or on the in-depth coverage of the PAIS Bulletin and the PAIS Foreign Language Index, please write or phone:

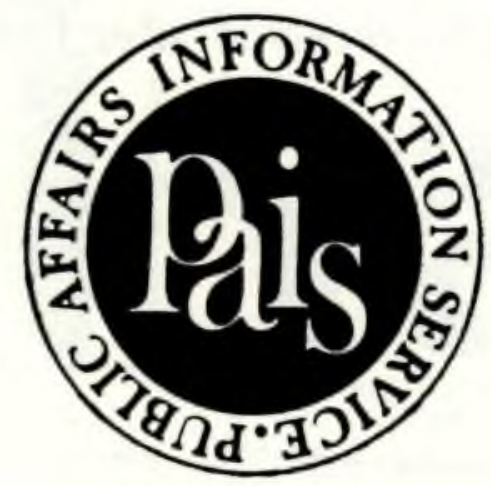

Public Affairs Information Service 11 West 40th Street

New York, N.Y. 10018

(212) 736-6629

PAIS is a nonprofit educational corporation founded in 1914 